\title{
Simultaneous action of surfactant modified clinoptilolite: Adsorbent of dyes and antibacterial agent
}

\author{
Muhammad Syafiq Abd Aziz, Nik Ahmad Nizam Nik Malek *, Siti Nabihan Ishak, Muhammad Hariz \\ Asraf, Atieya Abdul Hadi, Muhammad Zulhilmi Amir Awaluddin
}

Faculty of Biosciences and Medical Engineering, Universiti Teknologi Malaysia, 81310 UTM Skudai, Johor, Malaysia

* Corresponding author: niknizam@utm.my

\section{Article history}

Received 3 May 2018

Revised 25 August 2018

Accepted 11 September 2018

Published Online 25 October 2018

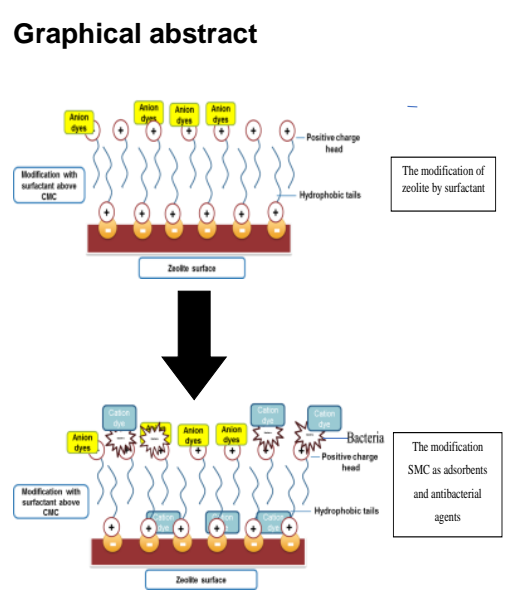

\begin{abstract}
In this study, the simultaneous action of surfactant modified clinoptilolite (SMC) as adsorbent for dyes and its antibacterial activity was investigated. Methylene blue (MB) and acid orange 7 (AO7) represent cationic and anionic dyes, respectively were used as adsorbate in this study and the antibacterial activity was studied against Gram-negative (Escherichia coli ATCC 11229) and Grampositive bacteria (Staphylococcus aureus ATCC 6538 and Enterococcus faecalis ATCC 2921). Initially, natural zeolite clinoptilolite was modified with 3 different concentrations $(0.1,1.0$ and 4.0 $\mathrm{mM}$ ) of cationic surfactant hexadecyltrimethyl ammonium bromide (HDTMA-Br). The SMC samples were characterized by Fourier transform infrared (FTIR) spectroscopy, X-ray diffraction (XRD), amount of HDTMA adsorbed and dispersion behaviour. Result from XRD shows that the HDTMA-Br molecules caused no effect on primary structure of the clinoptilolite since the clinoptilolite structure remained the same after modification with HDTMA-Br. Compared to the unmodified clinoptilolite, FTIR spectra of the SMC shows peak corresponds to $\mathrm{C}-\mathrm{H}$ stretches which proved the attachment of HDTMA onto the clinoptilolite surfaces. In the dispersion behaviour study, SMC samples were located at the adjacent phase between the water and oil mixture. The amount of HDTMA-Br adsorbed onto the clinoptilolite increased with the increasing concentrations of the surfactant. The use of SMC as adsorbent and antibacterial agent were further studied against the ionic dyes and bacteria simultaneously. The results show that the adsorption capacity of SMC towards both ionic dyes increase with the increasing HDTMA-Br concentration. While for the antibacterial activity, the number of colony forming unit of bacteria seem to be highly reduced at the highest concentration of the HDTMA (4.0 mM) attached on the clinoptilolite. Hence, this study had shown that SMC has high adsorption capacity towards the ionic dyes at the same time reducing the growth of both Gram positive and negative bacteria in aquoes solution.
\end{abstract}

Keywords: Clinoptilolite, Surfactant Modified Zeolite, Methylene Blue, Acid Orange 7, Antibacterial Agent

(C) 2018 Penerbit UTM Press. All rights reserved

\section{INTRODUCTION}

Nowadays, the advanced technology in the industrial application has led to various products to meet the needs of people. However, the improper use of chemicals in most of the products causes the world to suffer. The presence of many contaminants such as heavy metals, colouring dyes and harmful microorganisms in the wastewater and other aqueous solutions can seriously affect the environment and human health (Yang et al., 2012). There are several processes to remove these contaminants from wastewater such as desalination (Humplik et al., 2011), oxidation technology (Ebrahiem, AlMaghrabi, \& Mobarki, 2017), photocatalytic degradation (Li et al., 2016) and adsorption (Sadegh et al., 2017). Although many methods have been applied to overcome these problems, adsorption technique is the best approach compared to other techniques in term of their economical (Onundi et al., 2011), effectiveness for dye removal in wastewater ( $\mathrm{Li}$ et al., 2002) and sludge free operation (Sadon et al., 2012). There are many nanomaterials that have been introduced as nanosorbent of heavy metals including mesoporous silica (Vojoudi et al., 2017), magnetic sulfide ( Patel et al., 2018), carbon nanotubes (Coa et al., 2017)) and zeolite (Goyal et al., 2018). In this paper, natural zeolite which is clinoptilolite was chosen as an adsorbent as it is the most abundant and low cost. The unique physical properties like high surface area, negatively charged structure, high cation exchange capacity, high adsorption for certain pollutants (Armağan et al., 2004) and able to be modified with cationic surfactant (Apreutesei et al., 2008) without changing the structure has made it the best candidate for this research.

The modified zeolite that was treated with cationic surfactant hexadecyltrimethylammonium-bromide (HDTMA-Br) is able to attract the anionic compounds from the wastewater due to its positively charged bilayer formation on the zeolite surface (Malek and Yusof, 2007). Therefore, the surfactant-modified zeolite clinoptilolite (SMC) could adsorb the anionic dye in water. Research from Malek et al. (2014) proved that the SMC has antibacterial properties when combined with another cationic surfactant which is cetylpyridinium chloride (CPC).

The aim of this study was to modify the clinoptilolite with the cationic surfactant HDTMA-Br and characterized using X-ray diffraction (XRD), Fourier transform infrared spectroscopy (FTIR), HDTMA-Br adsorption and dispersion behaviour. The natural zeolite clinoptilolite and SMC were tested for the adsorption of methylene blue (MB) and acid oranges 7 (AO7) dyes. MB dye was chosen as it represented cationic compound while $\mathrm{AO} 7$ represented anionic compounds. For the antibacterial activity, Gram-negative (Escherichia 
coli) and Gram positive (Staphylococcus aureus and Enterococcus faecalis) bacteria were used in this study.

\section{EXPERIMENTAL}

\section{Materials}

The natural zeolite clinoptilolite was imported from Indonesia and supplied by Provet Group of Companies Sdn. Bhd, located in Serdang, Selangor. Cationic surfactant reagent (HDTMA-Br), was supplied by Qrec (Asia) Sdn. Bhd.

\section{Preparation of surfactant modified clinoptilolite}

The clinoptilolite was modified with three different initial concentrations of HDTMA-Br $(0.1,1.0$ and $4.0 \mathrm{mM})$. The HDTMA$\mathrm{Br}$ surfactants were prepared by dissolving $0.03645 \mathrm{~g}, 0.3645 \mathrm{~g}$ and $1.458 \mathrm{~g}$ of the HDTMA-Br powder into $1 \mathrm{~L}$ of distilled water in $1 \mathrm{~L}$ volumetric flasks. Accurately, $2 \mathrm{~g}$ of the clinoptilolite was then added in $200 \mathrm{ml}$ of the surfactant solution in a $250 \mathrm{ml}$ conical flask and stirred for 16 hours using magnetic stirrer at room temperature. The resulting SMC was separated from the HDTMA-Br solution by single filtration through Macherey-Nagel filter paper $(125 \mathrm{~mm})$ and dried at $80^{\circ} \mathrm{C}$ in a universal oven (model UF30, Memmert, Germany) overnight. The dried filtrate was ground into a fine powder by using mortar and pestle and sieved using \#40 American Society for Testing and Materials (ASTM) siever and the samples were kept in a suitable plastic container for characterization and adsorption study.

\section{Characterizations}

\section{Fourier Transform Infrared Spectroscopy (FTIR)}

All samples were characterized with a Thermo Scientific Nicolet iS5 with Smart iTR Diamond crystal FTIR (Fourier TransformInfrared) spectrometer. The instrument was used for the solid sample using attenuated total reflectance (ATR) method. The solid sample was ground using a mortar to obtain powder form. About 1-2 mg powder sample was then placed on the sample platform for the FTIR scanning spectrum and it was recorded using OMNIC software in the range of 400 to $4000 \mathrm{~cm}^{-1}$.

\section{X-Ray diffraction technique}

The phase identification of natural zeolite and SMC were determined using X-ray diffraction (XRD) method on a Bruker AXS $\mathrm{GmbH}$ (German) machine. X-ray diffraction patterns of all samples were recorded with a $\mathrm{CuK} \alpha$ radiation at $\lambda=1.5418 \AA$ at $40 \mathrm{kV}$ and 20 $\mathrm{mA}$ in the range of $2 \theta=5^{\circ}$ to $50^{\circ}$ with a scanning speed of $0.05^{\circ}$ per second.

\section{Amount of HDTMA-Br adsorbed on zeolite}

The amount of surfactant adsorbed onto clinoptilolite was determined according to the method described by Yusof et al. (2008) Approximately, $25 \mathrm{~mL}$ distilled water, $5 \mathrm{~mL}$ sulfuric acids $2 \mathrm{M}(\mathrm{RCI}$ Lab Scan, Thailand), $10 \mathrm{~mL}$ chloroform (QReC, New Zealand) and 2 $\mathrm{mL}$ acid orange $71 \mathrm{mM}$ (Sigma-Aldrich, USA) were mixed and shaken in a separating funnel. Following this, $1 \mathrm{~mL}$ from the sample solution was added to the mixture and was shaken vigorously. As a result, the colourless chloroform at the bottom layer from the mixture become light orange. The light orange layer was then separated and inserted into the bottle sample according to each concentration and analysed using visible spectrophotometer (model NANOCOLOR® VIS, Macherey Nagel, Germany) at $\lambda 487 \mathrm{~nm}$.

\section{Adsorption of acid orange 7 (AO7) and methylene blue (MB) on surfactant modified clinoptilolite}

The different concentrations of dye at 100, 200 and $400 \mathrm{ppm}$ were prepared. Then, $100 \mathrm{mg}$ of all the samples were accurately weighed and placed into $50 \mathrm{~mL}$ plastic tubes containing $25 \mathrm{~mL}$ of each concentration of dye solution. The mixture of dyes and samples were shaken constantly at $200 \mathrm{rpm}$ for 2 hours under room temperature.
The samples were separated from dye solutions by single filtration through Macherey-Nagel filter paper $(125 \mathrm{~mm})$ and the absorbance of the resulting filtrates were measured using Visible spectrophotometer (model NANOCOLOR ${ }^{\circledR}$ VIS, Macherey Nagel, Germany) at a wavelength of $487 \mathrm{~nm}$ for AO7 while $661 \mathrm{~nm}$ for MB dye adsorption.

\section{Dispersion behaviour}

In order to study the relative position in an oil-water mixture of unmodified and modified clinoptilolite an approximately $0.06 \mathrm{~g}$ of the sample was added in the mixture of distilled water $(2 \mathrm{~mL})$ and $\mathrm{n}$ hexane $(2 \mathrm{~mL})$ in a $10 \mathrm{~mL}$ glass bottle with stopper. The relative positions of the particles in the mixture were compared. After that, the samples were shaken for 2 hours at room temperature. The suspension formed were then left at static conditions. The images of all the samples were captured at an appropriate time before shaking, after shaking for 2 hours, static condition after shaking for 30 minutes and 24 hours

\section{Simultaneous action of zeolite and SMC}

The simultaneous action of clinoptilolite and SMC as adsorbent and antibacterial agent were studied against AO7 (Sigma-Aldrich, USA) and MB (Sigma-Aldrich, USA) for adsorption of dyes (Malek et al., 2016), while E. coli ATCC 11229 for Gram-negative bacteria and S. aureus ATCC 6538 and E. faecalis ATCC 2921 for Grampositive bacteria were used for antibacterial activity.

Bacteria culture that reached the OD reading between 0.6-0.8 (1.5 $\times 10^{8} \mathrm{CFU} / \mathrm{mL}$ ) at $4000 \mathrm{rpm}, 4^{\circ} \mathrm{C}$, for $15 \mathrm{~min}$ was centrifuged. The supernatant was discarded and the pellet was washed twice using distilled water. Following this, $50 \mathrm{ml}$ of the $10 \mathrm{ppm}$ dye solution were added into falcon tubes. Then, the falcon tubes were vortexed to suspend and disperse the bacterial pellet in the dye solution. After that, $0.1 \mathrm{~g}$ of the sample was weighed accurately into $50 \mathrm{ml}$ falcon tube and mixed with $20 \mathrm{ml}$ of the prepared dyes solution and bacterial culture. All the samples were incubated in an incubator shaker at $27^{\circ} \mathrm{C}$ (200 rpm) for $30 \mathrm{~min}$. After shaken for $30 \mathrm{~min}$, the sample was separated from mixed bacteria and dye solutions by single filtration through Macherey-Nagey filter paper $(125 \mathrm{~mm})$ and the absorbance of the resulting filtrates were measured using Visible spectrophotometer (BUCK 100 Vis Spectrophotometer, Jenway) to determine the concentration of AO7 (Sigma-Aldrich, USA) and MB (SigmaAldrich, USA) dyes at wavelengths of $487 \mathrm{~nm}$ and $661 \mathrm{~nm}$, respectively.

The number of bacteria presented after 30 mins of treatment with the natural zeolite, SMC0.1, SMC1.0, and SMC4.0 were determined by a serial dilution technique together with dropped plate (DP) method with slight modifications (Malek et al., 2014). In this study, the nutrient agar (NA) plate was divided into four quadrants, which each quadrant was reserved for one dilution factor of filtrates solution. Each quadrant was dropped with $10 \mathrm{uL}$ of the bacterial suspension from each falcon tube. After the drops on the agar dried, the plates were kept in an incubator at $37^{\circ} \mathrm{C}$ for $18 \mathrm{~h}$ and the reduction number of bacteria in Colony forming unit (CFU) in dye solution were calculated.

\section{RESULTS AND DISCUSSION}

\section{Adsorption of HDTMA-Br onto zeolite}

Based on Fig. 1, the result shows that the amount of HDTMA-Br adsorbed onto clinoptilolite increased with the increasing concentration of the surfactant. According to Erdogen and Ulku (2013), the adsorption occured due to the formation of electrostatic interaction and hydrogen bonding between the surfactant and the clinoptilolite surface. As the HDTMA-Br molecules positively charged, increasing the concentration of HDTMA-Br resulted in a higher affinity towards the negatively charged surface of clinoptilolite at the solid-liquid interface (Mi-Na et al., 2006). The adsorption of cationic surfactant onto negatively charged surface of clinoptilolite is attributed by two mechanisms which are ion exchange and hydrophobic bonding (Li et al., 1998). 


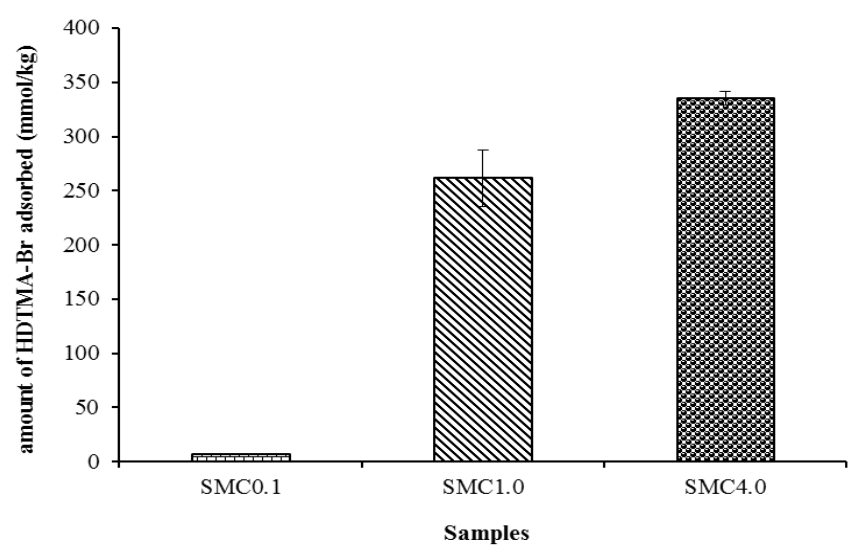

Fig. 1 : Amount of surfactant adsorbed by different concentration of HDTMA-Br SMZ0.1 (0.1mM), SMZ1.0 (1.0mM) and SMZ4.0 (4.0 mM) on clinoptilolite

The critical micelle concentration (CMC) plays an important role in the adsorption behaviour of HDTMA-Br molecules onto clinoptilolite. According to Cifuentes et al., (1997) the CMC value of HDTMA is $0.93 \mathrm{mM}$. At lower CMC, the surface tension of clinoptilolite changes strongly with the concentration of the surfactant where the surfactant molecules exist as monomers and retained on the surface of the adsorbent via ion exchange interaction (Li et al., 1998). At this stage, the SMC will have a low affinity or weak adsorption towards anion compound. After reaching the CMC or slightly increase from the $\mathrm{CMC}$, the surface tension remains relatively constant or changes with lower slopes that resulted in bilayer formation of micelles on the clinoptilolite surface. The internal layer of the micelle is attached on the adsorbent surface through ion exchange and the outer layer is anchored by hydrophobic interactions (Li et al., 1998). With the increasing concentration of surfactants, the bilayer formation of micelles on the clinoptilolite surface tends to reverse the negatively charge into positive charge surface and, therefore, this allow the SMC to adsorb anionic compounds (Zhu et al., 2014).

\section{Physicohemical properties of Zeolite and SMC}

\section{X-Ray diffraction}

$\mathrm{X}$-ray diffraction was used to identify and verify the compounds and crystalline structure in the clinoptilolite and SMC (Torres-Pérez et al., 2008). XRD patterns of the raw clinoptilolite and surfactant modified clinoptilolite (SMC) are shown in Fig. 2.

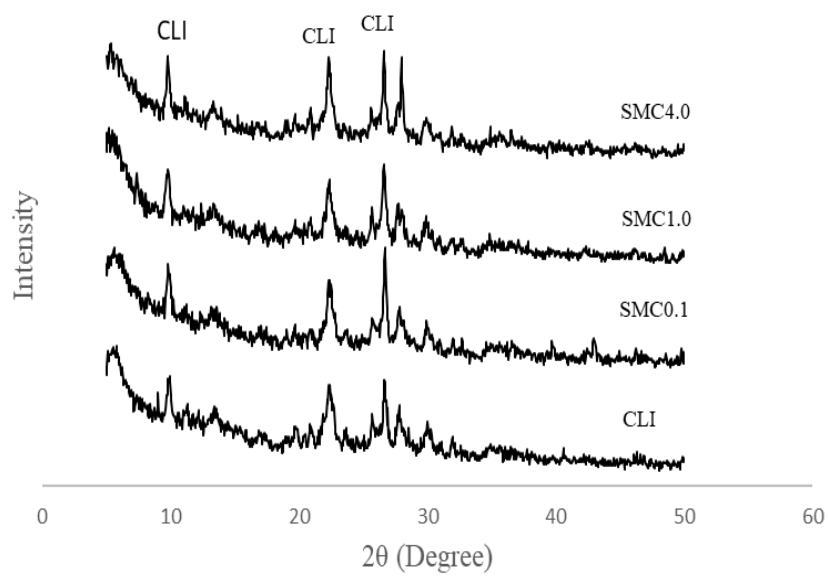

Fig. 2 : XRD pattern of the prepared samples.

Based on the patterns, it was observed that the main crystalline phase in the sample is clinoptilolite as the position of the intensities peaks were correspond to the clinoptilolite structure (Vassileva and Voikova, 2009). It was seen that clinoptilolite and quartz were the primary components in the natural zeolite samples and no present of clay minerals were detected (Torres-Pérez et al., 2008). It was also observed that SMC samples showed no significant changes in the position of the intense peak. Hence, the results showed that cation surfactant HDTMA-Br caused no effect on primary structure of clinoptilolite after modification process.

\section{Fourier transform infrared spectroscopy (FTIR)}

The FTIR spectroscopy was used for chemical identification in the samples of unmodified clinoptilolite and SMC (Kaushik et al., 2009). The comparison between both FTIR spectra of FTIR is shown in Fig. 3.

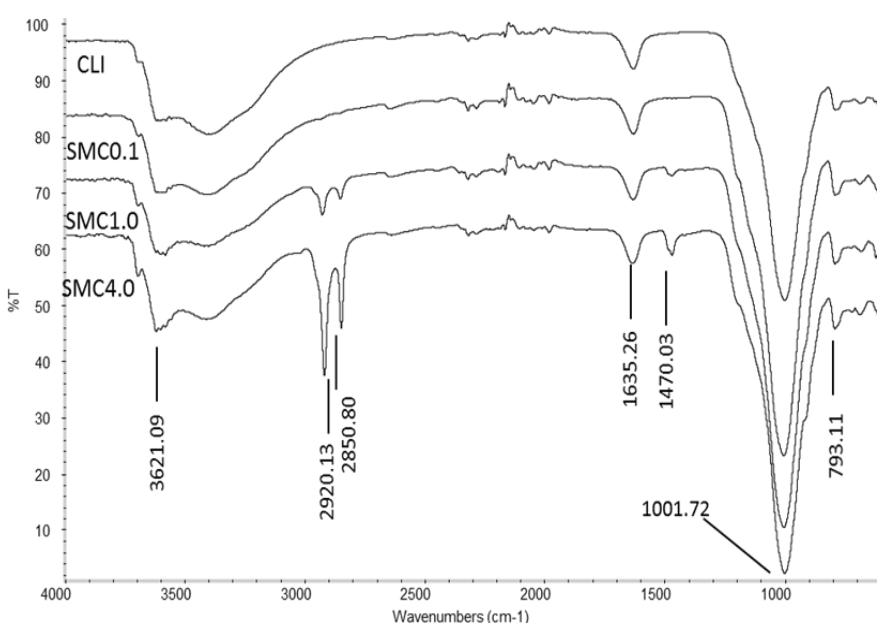

Fig. 3 : FT-IR spectra of the prepared samples.

FTIR spectroscopy was used to determine the presence of surfactant molecules on the clinoptilolite structure at around 3000 to $2800 \mathrm{~cm}^{-1}$. This is important region to identify two significant peaks when cationic surfactant was successful loaded onto the clinoptilolite (Li and Bowman, 2001). Based on the FTIR spectra, three additional peaks which are at 2920, 2850 and $1470 \mathrm{~cm}^{-1}$ are found for SMC1.0 and SMC4.0 which confirms the loading of HDTMA-Br on the clinoptilolite surfaces. The peaks found on the SMC represent the symmetric and asymmetric vibrations of the $\mathrm{C}-\mathrm{H}$ stretching modes, respectively, in the hydrocarbon chain of the HDTMA-Br compound (Malek and Ramli, 2015).

The presence of small peaks at $1470 \mathrm{~cm}^{-1}$ is assigned to the primary amino groups $\left(\mathrm{NH}_{2}\right)$ of the HDTMA-Br structure. Furthermore, the assignment of the $\mathrm{Si}-\mathrm{O}$ or $\mathrm{Si}-\mathrm{O}-\mathrm{Al}$ molecules that built up the structural framework of clinoptilolite can be seen from the corresponding wavelength within 600 to $1200 \mathrm{~cm}^{-1}$. The intense band at $1001 \mathrm{~cm}^{-1}$ is subjected to the internal T-O bonds in $\mathrm{TO}_{4}$ tetrahedral $(\mathrm{T}=\mathrm{Si}$ and $\mathrm{Al})$ stretching vibration (Tijani et al., 2013). Generally, the FT-IR spectra of SMC show that the clinoptilolite structure is not changed and remains intact after modification.

\section{Dispersion behaviour}

Dispersion behaviour of SMC and clinoptilolite was conducted to observe the relative position in which clinoptilolite would be occupied. This test can also demonstrate the changes in the surface properties of the SMC in comparison to unmodified clinoptilolite. This is because the surface of modified clinoptilolite may transform from hydrophilic to hydrophobic due to the attachment of hydrophobic molecules (surfactant) on its surface. Table 1 shows the optical images of the distribution of samples in hexane and water mixture. The sample of unmodified clinoptilolite was located at the lower layer of aqueous phase while the SMC sample is located at the adjacent phase between the water and oil mixture in the beginning. After shaking for 2 hours, both of the samples dispersed well in the water phase which is called colloidal dispersion. After static condition for 30 minutes and 24 hours, the unmodified clinoptilolite seems to locate at the lower layer of water phase while SMC samples still dispersed well in the water. These results support findings from other 
characterizaton results that the clinoptilolite surface is successfully modified by the surfactant molecules.

Tab. 1 : Dispersion behaviour studies of raw clinoptilolite and SMC in hexane and water mixture.

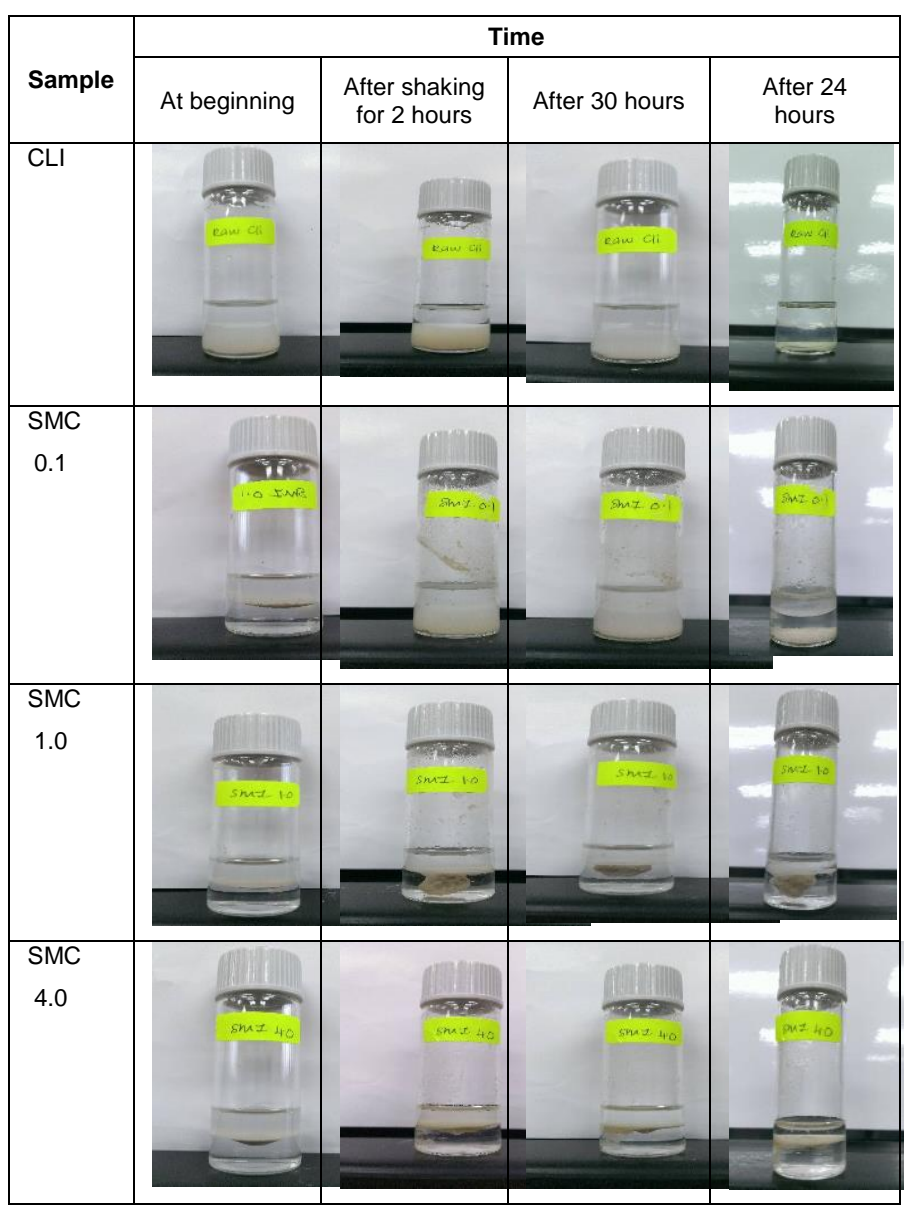

The organic phase of oil (upper layer) in SMC samples appears cloudy due to the presence of hydrophobic surfactant, while the organic phase in unmodified clinoptilolite appears to be clear. Surfactant contains hydrophobic and hydrophilic moieties which enable it to accumulate between fluid phases and thus, it can reduce surface and interfacial tension. This property contributes to the application of surfactant in various industries such as in agriculture, food and petroleum industries (Negin, Ali, \& Xie, 2017). Therefore, the attachment of surfactant onto clinoptilolite may change the surface property of clinoptilolite.

Clinoptilolite are originally hydrophilic in nature due to its high aluminium content (Chaouati et al., 2013). Attachment of surfactant as a monolayer onto clinoptilolite may change the surface of hydrophilic clinoptilolite to hydrophobic which is created by the surfactant tail groups (Li et al., 2001). This hydrophobic or organic coating on the surface of the clinoptilolite causes the clinoptilolite particles to avoid contact with the aqueous phase or water and partition itself in the organic phase (Bowman., 1991). This causes the position of the solid sample of raw clinoptilolite where the solid sample are positioned at the aqueous phase of the mixture.

\section{Simultaneous action of SMC: Antibacterial and adsorption}

The adsorption of both ionic dyes on the samples was analysed using visible spectrophotometer while the reduction of a number of bacteria in colony forming unit (CFU) in the dye solution was analysed for the antibacterial properties of the samples. Fig. 4, 5 and 6 show results of the simultaneous action of the prepared samples towards the dye solution and bacteria. (a)
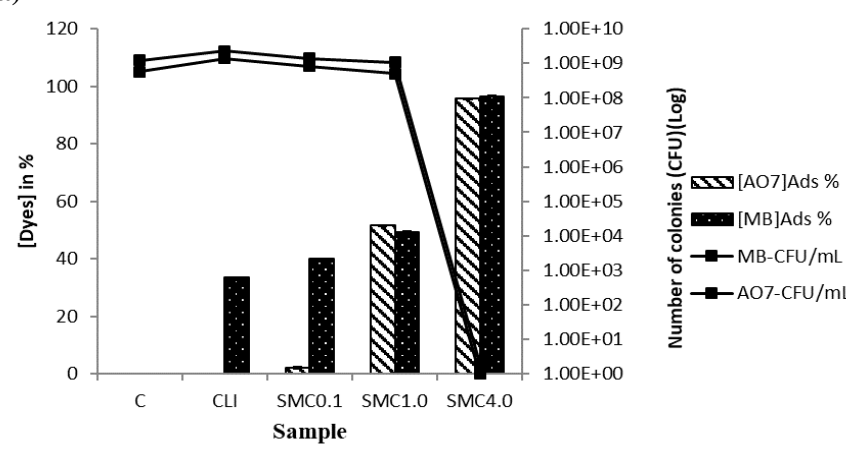

(b).

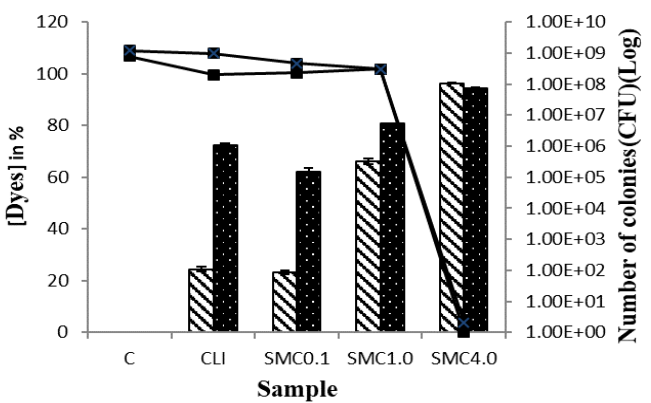

[OOO]Ads \%

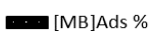

$\rightarrow-\mathrm{MB}-\mathrm{CFU} / \mathrm{mL}$

$\rightarrow-\mathrm{AO} 7-\mathrm{CFU} / \mathrm{mL}$

(c)

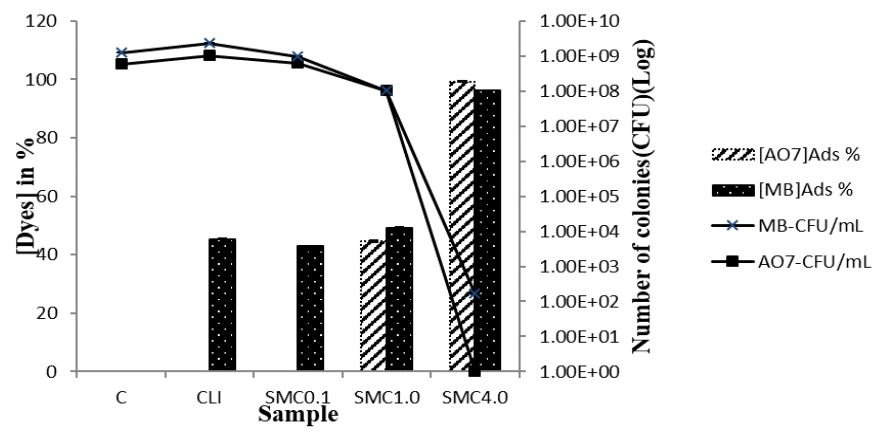

Fig. 4: Simultaneous action of SMC against $A O 7, M B$ dye adsorption and inhibition amount of (a) E.coli (b). S. aureus (c) E. faecalis.

Based on Fig. 4, the simultaneous actions of SMC against ionic dyes and bacteria showed better adsorption capacity and antibacterial activity with increasing concentrations of HDTMA-Br on clinoptilolite. The highest adsorption of $\mathrm{AO} 7$ and $\mathrm{MB}$ was found for SMC4.0 while for the antibacterial activity, there was no general trends could be observed. However, it was shown that the number of bacteria was reduced as the concentration of surfactant increased. The highest antibacterial activity by the samples towards both Gram positive and Gram negative bacteria was for SMC4.0.

The highest adsorption of AO7 by SMC4.0 was due to the presence of more HDTMA-Br molecules on the clinoptilolite. Clinoptilolite structure consists of a three dimensional framework having a negatively charge lattice. The negative charge that can be balanced by cations make it suitable to be modified with cationic surfactant HDTMA-Br (Qiu et al., 2009). Hence, modification of clinoptilolite surface with cationic surfactant can enhance the number of positive sites and eventually increase the adsorption capacity toward anionic dye. This can be due to the high electrostatic attraction between the positively charge surface of adsorbent (SMC) and AO7 dye molecules which are negatively charge. Furthermore, the degree of hydrophilicity plays an important roles in which the bilayer formation of admicelles positively charged group has a strong influence on the anionic dye uptake rather than monolayer formation (Torres-Pérez et al., 2008). Thus, by increasing the concentration of surfactant, it definitely increases the adsorption site of SMC towards 
anionic dyes through increasing positive charge on the surface. This was proven by the increasing percentage removal of anionic dyes by the SMC. While for the MB, the highest adsorption was also observed by SMC4.0. As the dye solution contains the presence of bacteria, i seems that SMC4.0 forming electrostatic interaction with the negative charge of bacterial protein. Since it was reported that bacteria cells have a tendency to adsorb certain cation pollutants (Luke et al., 2015), hence the bacteria could act as the intermediate between the SMC4.0 and $\mathrm{MB}$ in order to adsorb the cationic dye. However, this study are not evaluate the reaction between dye with just the bacteria cells

For the antibacterial activity, the reduction of number of both bacteria by the samples were the highest for SMC4.0. The antibacterial activity is related to chemical properties of the cationic surfactant that are capable to reduce the surface tension, form ionic aggregates, changes the conductivity and solubility of bacteria in water (Block, 2001). Futhermore, due to the positive charge of HDTMA, the high affinity to attract the negatively charged bacterial protein caused stresses in the cell wall which led to cell lysis and disruption of cell wall permeability of the bacteria.

\section{CONCLUSION}

Natural zeolite clinoptilolite has been modified with different concentrations of HDTMA-Br and the characterization results showed that the HDTMA molecules adsorbed on the clinoptilolite without distorting the zeolite structure although there is some changes in their physical characteristics mainly its dipersion behavior. The SMC with the highest amount of HDTMA (4.0 mM) showed the ability in adsorbing dyes and killing the bacteria simultaneously. Therefore, it can be concluded that the surfactant modified zeolite has two simultaneous actions which is as adsorbent and antibacterial agent which can be used for mny beneficial purposes in the future.

\section{ACKNOWLEDGEMENT}

This work was financially supported by the Universiti Teknologi Malaysia under the Research University Grant (Vot 18H87) and Ministry of Higher Education Malaysia.

\section{REFERENCES}

Apreutesei, R. E., Catrinescu, C., Teodosiu, C. 2008. Surfactant-modified natural zeolites for environmental applications in water purification. Environmental Engineering and Management Journal, 7, 149-161.

Armağan, B., Turan, M., Elik, M. S. 2004. Equilibrium studies on the adsorption of reactive azo dyes into zeolite. Desalination, 170, 33-39.

Block, S. S. 2001. Disinfection, Sterilization, and Preservation. USA: Lippincott Williams \& Wilkins.

Bowman, R. S., Sullivan, E. J., Li, Z. 2000. Uptake of Cations, Anions, and Nonpolar Organic Molecules by Surfactant-Modified Clinoptilolite-Rich Tuff. Natural Zeolites For The Third Millenium. International conference on the occurrence, properties, and utilization of natural zeolites. 1997. De Frede Editore, Naples, Italy, 287-297.

Chaouati, N., Soualah, A., Chater, M. 2013. Adsorption of phenol from aqueous solution onto zeolites $\mathrm{Y}$ modified by silylation. Comptes Rendus Chimie, 16, 222-228.

Cifuentes, A., Bernal, J. L., Diez-Masa, J. C. 1997. Determination of critical micelle concentration values using capillary electrophoresis instrumentation. Analytical Chemistry, 69, 4271-4274.

Clifton, L. A., Skoda, M. W., Le Brun, A. P., Ciesielski, F., Kuzmenko, I., Holt, S. A., Lakey, J. H. 2015. Effect of divalent cation removal on the structure of gram-negative bacterial outer membrane models. Langmuir, 31(1), 404-412.

Coa, F., Strauss, M., Clemente, Z., Neto, L. L. R., Lopes, J. R., Alencar, R. S., Souza, A. G., Alves, O. L., Castro, V. L. S. S., Barbieri, E., Martinez, D. S. T. 2017. Coating carbon nanotubes with humic acid using an eco-friendly mechanochemical method: Application for $\mathrm{Cu}$ (II) ions removal from water and aquatic ecotoxicity. Science of the Total Environment, 607, 1479-1486.

Ebrahiem, E. E., Al-Maghrabi, M. N., Mobarki, A. R. 2017. Removal of organic pollutants from industrial wastewater by applying photo-fenton oxidation technology. Arabian Journal of Chemistry, 10, S1674-S1679.
Erdogan, B. C. \& Ulku, S. 2013. Removal of bacteria by clinoptilolite rich mineral and its surfactant modified forms. Journal of Porous Materials, 20 1143-1151.

Goyal, N., Bulasara, V. K., Barman, S. 2018. Removal of emerging contaminants daidzein and coumestrol from water by nanozeolite beta modified with tetrasubstituted ammonium cation. Hazardous Waste and Hazardous Materials, 344, 417-430.

Humplik, T., Lee, J., O'Hern, S. C. 2011. Nanostructured materials for water desalination. Nanotechnology, 22, 292001.

Kaushik, C., Tuteja, R., Kaushik, N., Sharma, J. 2009. Minimization of organic chemical load in direct dyes effluent using low cost adsorbents. Chemical Engineering Journal, 155, 234-240.

Li, Z., Roy, S. J., Zou, Y., Bowman, R. S. 1998. Long-term chemical and biological stability of surfactant-modified zeolite. Environmental Science and Technology, 32, 2628-2632.

Li, R., Song, X., Huang, Y., Fang, Y., Jia, M., Ma, W. 2016. Visible-light photocatalytic degradation of azo dyes in water by $\mathrm{Ag}_{3} \mathrm{PO}_{4}$ : An unusual dependency between adsorption and the degradation rate on $\mathrm{pH}$ value. Journal of Molecular Catalysis A: Chemical, 421, 57-65.

Li, Z., Bowman, R. S. 2001. Regeneration of surfactant-modified zeolite after saturation with chromate and perchloroethylene. Water Research, 35, 322 326.

Li, Z., Alessi, D., Allen, L. 2002. Influence of quaternary ammonium on sorption of selected metal cations onto clinoptilolite zeolite. Journal Of Environmental Quality, 31, 1106-1114.

Malek, N. A. N. N., Ramli, N. I. A. 2015. Characterization and antibacterial activity of cetylpyridinium bromide $(\mathrm{Cpb})$ immobilized on kaolinite with different Cpb Loadings. Applied Clay Science, 109, 8-14.

Malek, N. A. N. N., Williams, C. D., Dhanabal, S., Bhall, H. S., Ibrahim, N. 2014. Natural clinoptilolite and chabazite as carrier for antibacterial agents of cetylpyridinium chloride $(\mathrm{Cpc})$ and silver. Applied Mechanics And Materials. Trans Tech Publications, 29-33.

Mi-Na, Z., Xue-Pin, L., Bi, S. 2006. Adsorption of surfactants on chromium leather waste. Journal-Society of Leather Technologists and Chemists, 90, 1.

Negin, C., Ali, S., \& Xie, Q. 2017. Most common surfactants employed in chemical enhanced oil recovery. Petroleum, 3(2), 197-211.

Onundi, Y. B., Mamun, A., Al Khatib, M., Al Saadi, M., Suleyman, A. 2011. Heavy metals removal from synthetic wastewater by a novel nano-size composite adsorbent. International Journal of Environmental Science \& Technology, 8, 799-806.

Qiu, M., Qian, C., Xu, J., Wu, J., Wang, G. 2009. Studies on the adsorption of dyes into clinoptilolite. Desalination, 243, 286-292.

Patel, K., Singh, N., Nayak, J. M., Jha, B., Sahoo, S. K., Kumar, R. 2018. Environmentally friendly inorganic magnetic sulfide nanoparticles for efficient adsorption-based mercury remediation from aqueous solution. Chemistry Select, 3, 1840-1851.

Sadon, F., Ibrahem, A. S., Ismail, K. N. 2012. An overview of rice husk applications and modification techniques in wastewater treatment. Journal of Purity, Utility Reaction and Environment, 1, 308-334.

Sadegh, H., Ali, G. A. M., Gupta, V. K., Makhlouf, A. S. H., Shahryarighoshekandi, R., Nadagouda, M. N., Megiel, E. 2017. The role of nanomaterials as effective adsorbents and their applications in wastewater treatment. Journal of Nanostructure in Chemistry, 7(1), 1-14.

Tijani, N., Ahlafi, H., Smaihi, M., El Mansouri, A. 2013. Preparation and characterization of $\mathrm{NaA}$ zeolite membranes and its application for removal of heavy metals. Mediterranean Journal of Chemistry, 2, 484-492.

Torres-Pérez, J., Solache-Ríos, M., Colín-Cruz, A. 2008. Sorption and desorption of dye remazol yellow onto a mexican surfactant-modified clinoptilolite rich tuff and a carbonaceous material from pyrolysis of sewage sludge. Water, Air, and Soil Pollution, 187, 303-313.

Vassileva, P., Voikova, D. 2009. Investigation on natural and pretreated bulgarian clinoptilolite for ammonium ions removal from aqueous solutions. Journal of Hazardous Materials, 170, 948-953.

Vojoudi, H., Badiei, A., Bahar, S., Ziarani, G. M., Faridbod, F., Ganjali,M. R. 2017. A new nano-sorbent for fast and efficient removal of heavy metals from aqueous solutions based on modification of magnetic mesoporous silica nanospheres. Journal of Magnetism and Magnetic Materials, 441, 193-203.

Yang, L., Ma, X., Guo, N. 2012. Sodium alginate/ $/ \mathrm{Na}^{+}$-rectorite composite microspheres: preparation, characterization, and dye adsorption. Carbohydrate Polymers, 90, 853-8.

Yusof A. M., Malek N. A. N. N. 2008. Removal of Cr(VI) and As(V) from aqueous solutions by HDTMA-modified zeolite Y. Journal of Hazardous Materials, 162, 1019-1024.

Zhu, J., Zhu, Y., Zhu, L., Rigutto, M., Van Der Made, A., Yang, C., Pan, S., Wang, L., Zhu, L., Jin, Y. 2014. Highly mesoporous single-crystalline zeolite beta synthesized using a nonsurfactant cationic polymer as a dualfunction template. Journal of the American Chemical Society, 136, 2503 2510 . 